\title{
RUSSELL AND WHITEHEAD ON THE PROCESS OF GROWTH IN EDUCATION ${ }^{\mathrm{I}}$
}

HOWARD WOODHOUSE

Educational Foundations / University of Saskatchewan

Saskatoon, Sask., Canada s7N owo

\section{RUSSELL, WHITEHEAD, AND PROCESS PHILOSOPHY}

$\mathrm{W}$

ere there no similarities between the philosophies of education of Bertrand Russell and Alfred North Whitehead, one would want to know why. Russell, after all, was Whitehead's student as an undergraduate at Cambridge, his colleague and collaborator for a dozen years working on the manuscript of Principia Mathematica published in three volumes from I9IO to 1913 , as well as his friend. Moreover, it was the sight of Whitehead's wife, Evelyn, in paroxysms of pain that prompted Russell's mystical experience in I9OI, during which he tells us that he became a humanist, pacifist, and advocate of free schooling. ${ }^{2}$

In this paper, I consider the question of whether or not Russell's account of the process of growth in education is compatible with that of Whitehead. The question is important because it enables one to

\footnotetext{
I Presented at the annual meeting of the Association of Process Philosophy of Education, American Philosophical Association Central Division Meeting, Chicago, 25-7 April 1991. Brian Hendley was the respondent. I would like to thank the audience for its penetrating questions, as well as Don Cochrane, Brian Hendley, John McMurtry and Viola Safr for their comments on an earlier draft.

${ }^{2}$ Auta., I: 149. For a psychoanalytic interpretation of Russell's "mystical illumination", see Bennett and Nancy Simon, "The Pacifist Turn: an Episode of Mystic Illumination in Russell's Life", Russell, no. I3 (Spring 1974): II-12, I7-24. Jo Vellacott believes that the term "pragmatic pacifist" more accurately describes Russell's approach to peace. See her biographical sketch of Russell in Harold Josephson, ed., The Biographical Dictionary of Modern Peace Leaders (London: Greenwood P., I983). 
determine whether or not Russell shares Whitehead's process approach to philosophy of education; namely one that conceives of learning as impossible without a desire to learn on the part of children, and as moving from a stage of romance through one of precision to one of generalization. ${ }^{3}$

In the second section of the paper, I concentrate on Russell and Whitehead's philosophical accounts of mathematics, the relationship between sense-experience and the physical sciences, and their respective interpretations of the importance of science to philosophy. In the course of this analysis, it will become clear that there are certain fundamental. differences between the two that suggest that Russell is not a process philosopher in any general sense. The question still remains, however, as to whether he is a process philosopher of education, and it is to this question that I turn in the third section by analyzing their concepts of organic growth in education. These are remarkably similar and had Russell maintained this concept, there might well have been grounds for thinking of him as a process philosopher of education. However, Russell later adopts a methodological behaviourism that conceives of the individual to be educated as a mechanism rather than an organism. I analyze this conceptual shift in the fourth section of the paper, arguing that it constitutes a diminution of his overall humanistic approach to education.

I had hoped to show that Russell was, in some sense at least, a process philosopher of education in that he took seriously the notions of interdependence, organic growth, and relational integrity that constitute such an approach. Many of his writings on education in particular suggest that he held just such a global, organic, and interdependent view of the problems facing humankind. ${ }^{4}$ Careful examination of the evidence, however, suggests that the philosophical basis of a process approach that would have grounded his views within a coher-

${ }^{3}$ Robert S. Brumbaugh, Whitehead, Process Philosophy, and Education (Albany: State U. of New York P., 1982), p. 17.

${ }^{4}$ See particularly Russell's Principles of Social Reconstruction (1916); Education and the Social Order (London: Allen \& Unwin, 1932), as well as his and Dora Russell's The Prospects of Industrial Civilization (New York: Century, 1923), and "The Place of Science in a Liberal Education" in Mysticism and Logic (London: Longmans Green,
I918) and Papers 8 and 12. ent philosophical framework is lacking in Russell's work.

In particular, Russell's emphasis on science as an analytic method that separates out the discrete elements of a problem in order to reach rational conclusions ensures that he understands the structure of the universe in an atomistic fashion as a set of isolated elements. This is evident in his abandonment of a humanistic conception of education, in which Russell sees individuals as embodying an organic principle of growth linking them to both the human species and the biological domain, for a mechanistic conception of education, in which Russell conceives of individuals as conglomerations of malleable instincts. Without a founding principle of growth, these instincts require the inculcation of a set of habits by means of a classical conditioning that takes no account of the emotional life of children. This kind of behaviourist approach meets Russell's criteria of being scientific because it enables those who use it to break down the different parts of human behaviour, reject consciousness and the subject of experience as unnecessary, and reach rational conclusions about the causal laws of human behaviour.' In doing so, however, Russell sets himself apart from process philosophy and process philosophy of education, since they both presuppose that different aspects of the universe cannot be isolated from one another without there occurring significant distortions in human understanding.

It should not be imagined that questions about the process of growth in Russell's philosophy of education and its relation to that of Whitehead are arcane issues on the periphery of Russell's philosophical enterprise. One of his central and abiding concerns was education, and the manner in which it could be changed to enable humanity to express itself in the free and open manner of which he believed it to be capable. If it can be shown that Russell's aim to educate children in fearless freedom" " was founded on a notion of freedom that denied to children the reality of their inner emotional lives and the possibility of their self-expression then the limitations of his philosophy of education become clear. Freedom within this context appears impossible,

s Howard Woodhouse, "Repression in Bertrand Russell's On Education", The Bertrand Russell Society, American Philosophical Association Eastern Division Meeting, Washington, D.C., December 1978 (paper on file in the Russell Archives).

${ }^{6}$ Russell, On Education (London: Allen \& Unwin, 1926), p. 248. 
since it amounts to children being moulded to accept the norms of society. I shall argue that this is precisely the view that Russell takes in On Education once he has abandoned his earlier emphasis upon the organic principle of growth. In its place, he conceives of children as mechanisms to be controlled by means of classical conditioning, in order that they can enjoy a fearless freedom within the limits laid down by such conditioning. This is not the kind of freedom normally associated with the name of Russell and his determination to bring into being a better world. 7

\section{RUSSELL A PROCESS PHILOSOPHER?}

I think it possible to summarize some of the major similarities and differences between Russell and Whitehead's philosophies in the following ways.

\section{A. Similarities}

(I) Both Russell and Whitehead believe mathematics to be an intrinsically valuable activity that provides an inclusive form of understanding and reveals a world of abstract ideas. ${ }^{8}$ Of these abstract ideas, relations among entities have great importance because their structure affords the mathematician the most general kind of knowledge. Numbers themselves, which are commonly thought of as individual integers enumerated in the process of counting, can better be understood, according to Russell, as members of a class or set. Their relationship both with other numbers and with the class itself makes intelligible the concept of infinite numbers, which otherwise remain undefined. ${ }^{9}$ Furthermore, mathematics makes possible for Russell and

${ }^{7}$ Ronald Jager, The Development of Bertrand Russell's Philosophy (London: Allen \& Unwin, 1972), pp. 425, 450 .

${ }^{8}$ Whitehead, The Aims of Education (New York: Free P., 1957), pp. 78-9; and Russell, "The Study of Mathematics" in Mysticism and Logic, pp. 53, 60 (also in Papers
I2).

${ }^{9}$ Russell, $M P D$, pp. 68-71. Under Whitehead's influence, when working on $P M$, Russell comes to abandon the mathematical notion of class (MPD, p. 75). For an analysis of this issue, see Alasdair Urquhart, "Russell's Zigzag Path to the Ramified Theory of Types" in Ian Winchester and K. Blackwell, eds., Antinomies and Paradoxes, Russell, n.s. 8 (I988): 82-91.
Whitehead the precise investigation of the natural world. Both the logical method and the precision of ideas that are learned in mathematics form the foundations of science and philosophy. Indeed, the structures of the physical world mirror those of mathematics, since they, too, are based upon relations among entities. ${ }^{10}$ The kind of understanding afforded by mathematics, therefore, is also the basis of philosophy, since it puts students in contact with long-lasting ideas having fundamental value, and enables them to gain a kind of liberation from the concerns of the everyday world.

(2) Both Russell and Whitehead uphold the idea that science is based on those kinds of sense-experience to which human beings have ready access (colours, sounds, smells, and observable objects, etc.). ${ }^{\mathrm{II}}$ The problem facing science at this point is to show how its generalizations are based upon these experiences. For Russell, induction fails because we can never prove the principle on the basis of experience without thereby begging the question. ${ }^{\mathrm{I} 2}$ This is because the principle of induction appeals to the future or to those unexperienced parts of the past or present with which we are not acquainted. As a result, Russell prefers to adopt a hypothetico-deductive method by which it is possible to move from the sense-experience of everyday life to a systematic understanding of the structures of the universe. In this way, science is able to progress by means of "an application of mathematical probability to premisses arrived at independently of induction." ${ }^{3}$ Whitehead also argues for the need for "careful scrutiny" in the manner in which we infer the existence of "the physical world [which] is, in some general sense of the term, a deduced concept." I4 In other words, like Russell, he prefers a more deductive kind of approach, suggesting that the theory of induction is the despair of philosophy.

\footnotetext{
to Whitehead, The Aims of Education, pp. 82, 84, 89, 134, 155-7. Russell, PoM, pp. 448-9, 471; PLA in $L K$, p. 207.

II Russell, "The Relation of Sense-Data to Physics" in Mysticism and Logic, pp. 145-79. Whitehead, of course, also includes feelings as integrating features of sense experience that allow us to relate the diverse elements of such experience into a unitary whole; see Process and Reality (New York: Free P., 1969), p. 244 and Part III.

${ }^{12}$ Russell, PP, Chap. 6. His argument is mirrored by Whitehead, op. cit., pp. $235-6$.

${ }^{13}$ Russell, $H K$, p. 45 I.

14 Whitehead, Aims of Education, pp. 164-5.

is Whitehead, Science and the Modern World (New York: Free P., 1967), p. 23; cf.
} 


\section{B. Differences}

While Russell and Whitehead agree on the need for philosophy to take into account the findings of modern science, they interpret the meaning of this statement in quite different ways.

(I) Whitehead integrates the theories of evolution and of relativity into his philosophy and infers that process is fundamental to organic growth, to spatiality and temporality, as well as to sense-experience. ${ }^{16}$ Events and processes are not governed by Newtonian causal laws that separate all of their constituent elements into discrete parts (e.g. time, space, object, etc.). Rather, they reveal indeterminate, interrelated organic, and physical structures that are linked to each other by spatiality and temporality.

(2) Russell, however, integrates the analytic methods of the natural sciences into his philosophy in order to make logical inferences and conjectures about the important problems that philosophy addresses. These include problems in the foundations of the a priori sciences (logic and mathematics), the foundations of the natural sciences (physics and $p s y c h o l o g y y^{17}$ ), and the foundations of the normative practices of education and politics. ${ }^{18}$ The same hypothetical and tentative method links Russell's analysis in all of these fields. ${ }^{19}$ In each case, he proceeds from clear logical formulations by means of analytic procedures to rational conclusions. ${ }^{20}$ The entire process is one of ensuring clarity about the evidence supporting certain beliefs.

This divergence in the interpretation of the relationship between philosophy and science entails quite different conceptions of both. Whitehead, on the one hand, places process at the core of his philos-

Aims of Education, pp. 145, 162; Process and Reality, pp. 235-6, and A. H. Johnson, Whitehead's Theory of Reality (Boston: Beacon P., 1952), p. 90.

${ }^{\mathrm{I}}$ Process and Reality, Part III; and $c f$. Robert S. Brumbaugh and Nathaniel M. Lawrence, Philosophers on Education (Boston: Houghton Mifflin, 1963), pp. 157-9.

${ }^{17}$ Russell considers psychological laws as analogues of physical laws in $A M i$, pp. 287-307.

${ }^{18}$ For a detailed analysis of Russell's method as uniting his philosophical approach to all of these disciplines, see my "Science as Method: the Conceptual Link between Russell's Philosophy and His Educational Thought", Russell, n.s. 5 (1985): I50-6I.

${ }^{19}$ Russell, "Philosophy and Politics" in Unpopular Essays (London: Allen \& Unwin, 1950), p. 27.

${ }^{20}$ Mario Bunge, "Bertrand Russell's Regulae Philosophand", in Bunge, ed., The Methodological Unity of Science (Dordrecht: Reidel, 1973), pp. 3-I2. ophy because the notion of interrelatedness emerges from the theories of evolution and of relativity. Process is fundamental to knowledge in both of these powerful scientific theories. Russell, on the other hand, places analysis at the core of his philosophy because philosophy can thereby imitate the methods of science which he considers to be the surest path to knowledge. For Whitehead, science constitutes substantive theories showing reality to be a series of processes and events. For Russell, however, science consists of methods of analysis that subject all problems to precise formulations, analyses, and rational conclusions. Clearly missing from Russell's account is any notion of process or interrelatedness. ${ }^{2 \mathrm{I}}$ The only kind of process that Russell posits is that of the scientific method itself, and its purpose is to separate out the various elements of a problem in order to be clear about its nature and formulation. In other words, Russell's concept of the scientific method is antithetical to Whitehead's concept of process because its aim is to separate, distinguish, and isolate different parts of reality from one another in order to arrive at clear, rational conclusions. For Whitehead, however, a full understanding of any physical process must take into consideration the interrelatedness of spatiality and temporality in both the physical world, which is deduced by means of "careful scrutiny", and the world of "fragmentary individual experience" ${ }^{\prime 2}$ to which the observer has direct access. We can now see that this notion of interrelatedness is absent from Russell's philosophy in which all relations in the physical world are ultimately comprehensible by means of a process of analysis that breaks down the whole into its constituent parts.

To the extent that Russell rejects the concept of process, he cannot be considered a process philosopher. Having shown how and why this is the case, I wish now to turn to a consideration of whether or not he

${ }^{21}$ Russell, of course, takes into account the most recent developments in physics such as the theory of relativity and quantum mechanics. However, he interprets them as supporting the theory of neutral monism, in which mind and matter are constructs from the same set of events, rather than as establishing the interdependence of the observer and the observed. See his $H W P_{3}$, pp. 786-8.

${ }^{22}$ Whitehead, Aims of Education, pp. 164, 163 and $c f .146-7$. However, in Russell's early view of physics, space and time were absolutes: see Ian Winchester, "The Antinomy of Dynamical Causation in Leibniz and Principles and Russell's Early Picture of Physics" in Antinomies and Paradoxes, Russell n.s. 8 (1988): 35-45. 
can be considered a process philosopher of education by examining the conceptual links between his and Whitehead's concept of organic educational growth.

\section{ORGANIC GROWTH IN RUSSELL AND WHITEHEAD'S EDUCATIONAL PHILOSOPHIES}

During and shortly after the First World War, Russell first enunciated his concept of growth as the organic basis of the individual. This concept is fundamental to his humanistic conception of education, just as it is to Whitehead's. In this section, I analyze both conceptions of growth in order to show that, while Whitehead's concept of rhythmic cycles may be more precise than Russell's, the two are very similar. It is not until section 4 that later fundamental differences between the two educational philosophies are analyzed.

\section{A. Russell on Growth}

Russell begins his account of human organic growth by recognizing the importance of impulses and desires in the lives of human beings:

The impulses and desires of men and women, in so far as they are of real importance in their lives, are not detached one from another, but proceed from a central principle of growth, an instinctive urgency leading them in a certain direction, as trees seek the light. So long as this instinctive movement is not thwarted, whatever misfortunes may occur are not fundamental disasters, and do not produce those distortions which result from interference with natural growth. This intimate centre in each human being is what imagination must apprehend if we are to understand him intuitively. It differs from man to man, and determines for each man the type of excellence of which he is capable. The utmost that social institutions can do for a man is to make his own growth free and vigorous: they cannot force him to grow according to the pattern of another man. ${ }^{23}$

Here, Russell suggests the following as important to the concept of growth:

(I) In comparing the growth of human beings to the natural growth

${ }^{23}$ Russell, PSR (Ist ed. 1916; London: Allen \& Unwin, I96o), p. I9. of organisms, he places human development within biological development.

(2) The principle of growth itself is an innate structure upon which the organic development of human beings is based.

(3) In defining the principle of growth as the unifying source of impulse and desire, he conceives of individual misfortunes as unessential, provided that they do not thwart the principle's development.

(4) In conceiving of intuition and imagination only as capable of apprehending the intimate centre of each individual, he calls for the necessity of caring and sensitive educational relations.

(5) Finally, in stating that this centre differs from person to person, he is able to recommend that the task of social institutions is the liberation of the individual's potential for excellence rather than the inculcation of fixed and pre-determined patterns.

Russell thus articulates a concept of the individual that is grounded in both the species nature of humankind (rooted in a universal principle) and in the uniqueness of each person (rooted in distinctive instinctual growth patterns).$^{24}$ Indeed, he intends the metaphor of growth to apply to human development in both the physical and mental spheres. ${ }^{25}$ While air, nourishment, and exercise aid healthy physical development, Russell recognizes that the external conditions that enhance healthy emotional and intellectual growth are more complex:

Men, like trees, require for their growth the right soil and a sufficient freedom from oppression. These can be helped or hindered by political institutions. But the soil and the freedom required for a man's growth are immeas-

${ }^{24}$ The notion of humans as species beings is that of the young Marx. In realizing their species-character, human beings, unlike animals, make of themselves and their productive life "an object of their will and consciousness" and are capable of "free conscious activity". In other words, man "is only a self conscious being, i.e. his own life is an object for him because he is a species-being" (Karl Marx, Early Writings, trans. and ed. T. B. Bottomore [New York: McGraw-Hill, 1963], p. 127). Noam Chomsky also indicates that Russell's humanistic conception of human beings bears certain similarities to that of the young Marx, especially in his emphasis upon the free development of the individual; see Chomsky, Problems of Knowledge and Freedom: the Russell Lectures (New York: Random House, 1971), p. 54 .

${ }^{25}$ Russell, Political Ideals (Ist ed. 1917; London: Unwin Books, 1963), p. I3. 
urably more difficult to discover and to obtain than the soil and the freedom required for the growth of a tree. And the full growth which may be hoped for cannot be defined or demonstrated; it is subtle and complex, it can only be felt by a delicate intuition and dimly apprehended by imagination and respect. (PSR [1960], pp. I9-20)

In order to secure this emphasis upon imagination, respect, and subtlety on the part of the adult in cultivating growth in children, Russell articulates two general principles. The first of these is the traditional principle of liberty, which entails non-interference with the rights of all men and women to pursue their own ends, provided that they, in turn, do not interfere with the liberty of others. With regard to education, the principle entails that children also enjoy the right to self-expression by being free from those influences that deny them autonomy in the intellectual or moral domains. ${ }^{26}$ Russell now finds himself at odds with much educational theory of both his own day and ours. Such theories assert that children should learn moral values in a context where teachers and principles exert strong authority over them. ${ }^{27}$

The second of Russell's principles is reverence, which he wants applied in society in general but which has particular importance for education. It goes beyond the principle of liberty in justifying much more than simple non-interference on the part of the adult in children's educational development. If adults are imbued with reverence, they will feel a certain humility in the presence of children and will take seriously children's own autonomy. As Russell puts it:

The man who has reverence will not think it is his duty to "mould" the young. He feels in all that lives, but especially in human beings, and most of all in children, something sacred, indefinable, unlimited, something individual and strangely precious, the growing principle of life, an embodied fragment of the dumb striving of the world. (PSR [1960], p. 102-3)

Reverence for children encompasses both an understanding that the

${ }^{26}$ PSR, p. 66. Cf. Christian Bay, The Structure of Freedom (Stanford: Stanford U. P., 1958$)$, pp. $127-8$.

${ }_{27}$ Understanding the Common Essential Learnings: a Handbook for Teachers (Regina: Saskatchewan Education, August 1988), p. 45. principle of growth is striving for expression in them and an almost spiritual respect for this emerging process. It also implies an active caring and concern for the well-being and self-expression of the young on the part of the educator, ${ }^{28}$ in addition to a realization of the need to provide an environment suitable for the channelling of their impulses towards constructive activities. Children, after all, are unique beings, endowed with various capacities, some of which they share with the rest of humankind and others which are peculiar to themselves. These capacities can only be forged into a cohesive whole through a process of growth in which children actively develop their own inner freedom: a freedom that is founded directly on the principle of growth.

The metaphor that Russell uses to capture the nature of this reverential relationship between adults and children is that of gardeners to their plants. This is in keeping with his overall emphasis on the importance of the organic principle of growth that education is to develop. As he and Dora Russell put it:

The humanistic conception regards a child as a gardener regards a young tree, i.e. as something with a certain nature, which will develop into an admirable form, given proper soil and light. (Prospects of Industrial Civilization, pp. $274-5)$

As has already been mentioned, Russell is only too aware that the kinds of conditions necessary for ensuring constructive growth in human beings are much more complex than those necessary for growing healthy plants or trees. Nevertheless, both processes are rooted in biological development and in the determination of the appropriate ways to cultivate young saplings. The analogy extends to the cultural process of education, not only because human growth is rooted in biological growth, but also because the educational relationship (like the gardening one) is based on a caring, nurturing, and tending approach on the part of the adult. ${ }^{29}$ Only when these conditions are

${ }^{28}$ Cf. Nel Noddings, Caring: a Feminine Approach to Ethics and Moral Education (Berkeley: U. of California P., I984).

29 I have considered this question at greater length elsewhere. See "The Concept of Growth in Bertrand Russell's Educational Thought", The Journal of Educational 
fulfilled will the young be educated in the original sense of the term namely, of being caused to grow. ${ }^{30}$

In order to grow in constructive, self-directed ways, children also need to acquire a self-discipline that will give them a sense of purpose. Only a discipline that issues from within will be sufficient for this task, since the externally imposed kind deadens both growth and the spirit of inquiry. Russell thereby acknowledges that an outwardly directed will is necessary for becoming a self-disciplined, purposeful, integrated individual, interested in social and intellectual matters. Outward will is to be directed towards tasks in which the individual meets opposition or difficulty; for example, intellectual pursuits in which the confrontation with boredom or complexity are inevitable. It is also to be found in the activities of all those who lead vigorous, active, constructive lives ( $P S R$, pp. III, I64-5).

Russell believes that it is possible for the young to learn this kind of self-discipline without the kind of compulsion that accompanies it in schools. Rather, where a growing child or adolescent has expressed interest in an intellectual pursuit, a caring adult, imbued with reverence, will be able to spur the child or adolescent's ambition to pursue it further by means of careful advice and by "appealing to the pupil's consciousness of his own needs" (PSR, p. II2). If appeal is made to the developing interests of the young, even those who are not the most intellectually gifted are likely to love learning rather than despise it. For those who continue on to higher education, one of the gifts that await the learner is precisely this capacity for self-discipline, combined with a "joy of mental adventure [which] is the supreme end for which the education of the mind is valued" (ibid., pp. II4-I5). At this stage of education, individuals learn to combine their "intellectual impulse of curiosity" (ibid., p. I3) with a good deal of self-discipline, a keen critical ability in the pursuit of truth, and a renewed sense of joy in

Thought, 17 (1983), and "More than Mere Musings: Russell's Reflections on Education as Philosophy", Russell, n.s. 7 (1987): 176-8, where I refer to Russell's humanistic theory of education as "romantic". For this I have been criticized by Bansraj Mattai, "Education and the Emotions: the Relevance of the Russellian Perspective", Russellai, (1990): I4I-57.

30. Cf. John McMurtry, "The History of Inquiry and Social Reproduction: Educating for Critical Thought", Interchange, I9 (1988): 31-5. the pursuit of knowledge. This process is insufficiently constructive for Russell, however, who proposes a broader spiritual aim for educating individuals to contemplate the most general aspects of life and to experience:

[T] he joy of universal love ... [which] gives freedom and breadth and beauty to men's thoughts and feelings, and to all their relations with others ... [and which] restores harmony between mind and instinct. (Ibid., p. 154)

The fullest kind of development integrates the instinctual principle of growth with the self-discipline of mental adventure and confers a spiritual understanding of the universe upon individuals that unites their lives. This process is perhaps most clearly fulfilled in education where a sense of reverence for the child's principle of growth and for his or her potential in the mental and other spheres requires of educators a sense of spiritual wonder and a concern for all aspects of human development.

\section{B. Whitehead on Growth ${ }^{31}$}

For Whitehead, all education begins with romance, that instinctive curiosity and joy for learning that typifies children's apparently unquenchable thirst for knowledge. Unlike Russell, Whitehead refers to both romance and the two subsequent stages of education as "rhythmic cycles" to be respected by all education so as to be in tune with the organic growth of children. In the cycle of romance, children's innate curiosity is to be given the fullest possible leeway. Indeed without an enduring sense of romance, children's desire to know will have little chance of find enduring satisfaction (Aims of Education, pp. I7-18, 27-8).

The second rhythmic cycle of education is precision. It is now that children learn the importance of the structures of the different subjectmatters that they have been learning. In learning their own mother

${ }^{3 I}$ I have been greatly helped in my interpretation of Whitchead's philosophy of education by the following works: Brumbaugh and Lawrence: op. cit., Chap. 7; Brumbaugh, "Why Whitehead? A Justification for the Association for Process Philosophy of Education", Association for Process Philosophy of Education, Publication No. 88-I, Dec. 1988; and Brian Hendley, Dewey, Russell, Whitehead: Philosophers as Educators (Carbondale: Southern Illinois U. P., I986), Chap. 4. 
tongue, for example, a phase is reached at which it becomes necessary to understand its grammatical structures so that the child can learn to communicate with others as precisely as possible. Romance is not forgotten but becomes secondary to the need for precision. Fortunate$\mathrm{ly}$, the need for precision is not required at the same time in all subject-matters, since language learning will have started much earlier than the study of science, mathematics or even history. Structure and precision is vital to each of these disciplines and Whitehead recognizes its importance (ibid., pp. $18-19,22-5,31$ ).

The third cycle is that of generalization in which adolescents learn to utilize the precise knowledge that they have gained to arrive at more general kinds of knowledge. This involves making connections either within the structures of one discipline or between different disciplines. In coming to such a general understanding (which, as I have pointed out, both Whitehead and Russell thought was possible through the study of mathematics), the young reach far beyond the cycle of precision to a general form of knowledge that constitutes another cycle of romance (ibid., pp. 19, 25-7, 37, 39, 93-8). In other words, learners integrate both romance and precision in their quest for knowledge and continue upward in the cycle to a revitalized level of learning based on joy and romance. This, for Whitehead, is the basis of higher education: a desire to gain the most general forms of knowledge, fortified by a lasting sense of romance for both the quest and for knowledge itself. In the same way, the first cycle of romance corresponds roughly to the way that elementary education should be conducted, while precision corresponds pretty much to secondary education. $^{32}$

Whitehead places educational growth squarely within overall organic growth. In other words, the rhythmic cycles that must be observed if education is to be successful are cycles that repeat themselves in every form of organic life, not just in humans. It is for this reason that they are of fundamental importance and why failure to observe and respect them is likely to result in unsuccessful education (ibid., pp. 2I-2, 27, 3I-3). What is remarkable about Whitehead's

${ }^{32}$ Whitehead warns of distinguishing too sharply among the cycles of growth which operate in each cycle as well: Aims of Education, pp. 27-8, 37-8. account of these rhythmic cycles is that he should consider them as cycles at all. Most biologists or psychologists who have been influenced by the theory of evolution (Piaget, for example) have represented human life as a set of discrete stages along a linear path of development. Yet, Whitehead conceives of organic life in general, and human life in particular, as a series of cycles succeeding each other in a spiralling process that forms an overall cyclical pattern of growth. While this account may find support in the most recent biological theories (the Gaia hypothesis, for example), it has still not become the norm in most of the sciences. ${ }^{33}$ Just as interestingly, a cyclical view of biological and human life is shared by the traditional cultures of the indigenous peoples of Africa and North America. ${ }^{34}$ Whitehead's theory may therefore be of considerable importance in the task of developing a new understanding in concert with the needs and aspirations of these various peoples.

\section{Growth as Organic Process}

Whitehead captures some of the distinctive features of organic growth by contrasting it with the development of a mechanism:

In the production of a mechanism the constructive energy lies outside it, and adds discrete parts to discrete parts. The case is far different for a living organism which grows by its own impulse towards self-development. This impulse can be stimulated and guided from outside the organism, and it can also be killed. But for all your stimulation and guidance the creative impulse towards growth comes from within, and is intensely characteristic of the individual. (Ibid., pp. 38-9)

This passage is reminiscent of Russell's analysis of the principle of growth. Both men emphasize the need to allow creative impulses to develop in constructive ways and the role of the adult as one who enables this process to unfold in a self-directed way. Whitehead makes no mention of the need for reverence towards the child on the part of the educator, ${ }^{35}$ while Russell omits completely the notion of cycles of

${ }^{33}$ Cf. David Suzuki, Inventing the Future (Toronto: Stoddart, 1989).

${ }^{34}$ Cf. my "Moral and Religious Education for Nigeria", The Journal of Moral Education, I3 (1985): I2I-3I.

${ }^{35}$ Nevertheless, Whitehead recognizes the importance of reverence in education in 
rhythmic growth. However, Russell does write of the initial promptings of innate curiosity in the child, followed by a need for self-discipline, and finally a search for general knowledge, combined with universal love. All of this is similar to Whitehead's theory, although Russell may be less exact in the manner in which he analyzes the process of organic growth. At the same time, by comparing human growth to that of plants and trees, Russell clearly acknowledges that both processes are organic and biological in nature. Furthermore, as already mentioned, the principle of reverence enables the educator to recognize both the instinctive principle of growth and the spiritual aspect of young children as having fundamental importance to the process of education.

If these were the only differences between the two theories then it would be tempting to think of Russell as a process philosopher of education. However, as I shall show in the next section, Russell comes to abandon the organic principle of growth at the core of his educational philosophy and replaces it with a mechanical conception of human development of the very kind that both he and Whitehead have been at pains to reject.

\section{RUSSELL AS MECHANIST}

\section{A. Mesmerized by Clockwork Efficiency}

After Russell marries Dora Black, and by the time they jointly educate their children and start Beacon Hill School, he has abandoned the notion of organic growth as the core of his humanistic concept of education. Russell writes of his newly adopted views in On Education (1926), where he conceives of children as mechanisms to be educated by means of the correct set of habits. These habits are to be inculcated by a strict regime that leaves young infants alone to cry at night, for example. Children who fear to swim in the sea can be liberated from their fear by being conditioned to the sound of the waves, slowly encouraged and introduced to the water itself, and finally taken against their will, held by the arms, and dunked in the brine. ${ }^{36}$

a rather different sense. Educators must recognize the vision of the cosmos that can be created and realize this pedagogically by developing activities that capture its unfolding structures. See Brumbaugh, "Why Whitehead?", p. I4.

${ }^{36}$ A. S. Neill wrote to Russell about this use of "traditional methods", complaining
When he reports the success of this method in the case of his own son, John, Russell writes as follows: "Fear had not ceased altogether, but had been partly repressed by pride. Familiarity, however, made the fear grow rapidly less, and it has now ceased altogether" (On Education, p. 88). It is remarkable to note the fundamental differences between this approach to the education of his son and Russell's earlier organic conception of children. There are, indeed, three distinguishing features that make it quite unlike the earlier theory:

(I) The explicit use of praise and blame in trying to coax John into the water. Russell does recognize their potentially destructive effects and recommends that praise and blame be used only sparingly (ibid., p. 77).

(2) The use of force against children, to which Russell is generally averse but which he favours in instances where children's fear is both irrational and strong. Left to themselves, children, it seems, will not gain the necessary experience to find out that their fears are groundless (ibid., p. 88).

(3) The need to repress children's instinctual fear by appeals to their pride. Until the experience of the water became familiar, John continued to be afraid of it, and screamed and shouted, according to Russell. The growing feeling of pride, combined with the need for social approval, was necessary for John to control his fear. The net result was that pride now replaced fear, and the chief mechanism by which this process was achieved was selfcontrol. It is worth noting that the "success" of the process is achieved against the child's will and does nothing to allay any deeper fears that he or she may have about water or any other aspects of the environment that elicit fear. Indeed, the kind of self-control that Russell is recommending is quite unlike the self-discipline of his earlier humanistic theory, where an appeal to children's needs was made in order to develop more disciplined intellectual habits, for example. As a result, fear is now displaced by means of habits that are externally imposed by force. To this

that they might make a child more introverted. See Ray Hemmings, Children's Freedom (New York: Schocken Books, 1973), p. 78. The same method was used on Russell as a child. See Auto. 3: 64 . 
extent, they result in just that kind of repression to which Russell objected in his earlier theory because they drive the original fear into the unconscious.

Russell has now come to believe that repression is necessary in order to develop the kind of control over instinctual fears in the young required for physical exercise: "I think, therefore, that the early acquisition of habits of self-control in the matter of fear, and the early teaching of physical enterprise, are of sufficient importance to warrant somewhat drastic methods" (On Education, p. 89). The "drastic methods" to which Russell is referring are precisely those he has applied in the case of John's fear of the sea. His main reason for adopting them is that he now believes it necessary to instill the correct habits among the young that will make desirable behaviour "almost automatic": in this case, the "physical enterprise" of John's learning to swim (ibid., p. 35). Without an organic principle of growth as the source from which they stem, the impulses and desires of children become an anarchic encumbrance to Russell's mechanistic theory that require both externally imposed control and a process of classical conditioning, resulting in the correct set of habits in children.

Absent from Russell's account is any notion of the internal disequilibrium that his proposed process of control engenders in children. Having classified all fears as either instinctive or learned, he proceeds to overlook any internal motives that may have prompted such fears in the first place (e.g. John's apprehension of physical activity controlled by adults). According to Katharine Tait, Russell totally neglected the inner emotions of her brother in his treatment of John's fears:

He did not regard them as manifestations of psychological distress unable to express itself in any other ways. It was as though the child had no internal life of its own, only an external surface to be moulded according to the parent's desire. ${ }^{37}$

The dominant aim of moulding the child, combined with a neglect of his emotional life, makes Russell's approach to child-rearing totally one-sided. Indeed, Russell himself becomes “... mesmerized by the

${ }^{37}$ My Father Bertrand Russell (New York: Harcourt Brace Jovanovich, 1975), p. 64. authorities ... of that early behaviourism whose clockwork efficiency embittered the infancy of so many of my generation" (ibid., pp. 6I, 59). As a result, Russell declares that behaviourism is "the only valid method for the study of animal and child psychology." 38

Russell's conception of children corresponds to the notion of mechanism that Whitehead criticizes in a passage from The Aims of Education quoted earlier. Here Whitehead points out that, in the production of a mechanism, any constructive energy lies outside the mechanism itself, residing in the people who make it. They manage to construct the mechanism itself by adding together separate components that go to make up the whole. In Russell's behaviourist account of children, this is precisely how education takes place. Habits instilled from outside, by force where necessary, are added on as discrete parts to children's own instincts, displacing or repressing those that stem from deeply based fears. Rather than conceiving of children as organically whole in which all the various parts inhere, Russell now considers these as constructs of separate parts (e.g. learned fears, instinctive fears, reflexes, etc.) to be held together by a set of correct habits.

In order to understand how Russell became so mesmerized by behaviourism's programme to instill a mechanical regime of efficient habits in children constructed, as it were, out of discrete parts, it is necessary to examine his philosophical reasons for adopting the theory.

\section{B. Behaviourism as Scientific Method}

In The Analysis of Mind (1921), Russell considers that behaviourism is capable of transforming psychology into a science. This is because behaviourism embodies those aspects of the scientific method that Russell holds to be important; namely, an ability to subject problems to precise formulations and analyses, from which rational conclusions can be inferred by means of a process of separating, distinguishing, and isolating the different aspects of the problems in question (MPD, p. 133). Furthermore, behaviourists agree that physics is the most fundamental of the sciences and that the task of psychology is to emulate the manner in which physics formulates its laws. This involves the use of the most precise mathematical methods, which can now be applied

38 "The Training of Young Children", Harper's Magazine, I55 (Aug. 1927): 314. 
to both matter and human behaviour. In psychology, this process will lead to the establishment of causal laws, showing how human behaviour is determined, as well as the formulation of precise predictions about the mechanisms of desire in humans. This will be done in just the same way as predictions are already made about the mechanism of desire in birds and other animals. ${ }^{39}$

The clear scientific advantages to such a theory are fortified by a second prong to Russell's argument, which he adopts from William James. Neutral monism, like behaviourism, dispenses with consciousness, preferring sensations as the building blocks upon which a theory of mind can be based. Sensations are distinguished by their lack of intentionality, or the property of directedness towards the world that characterized consciousness. When sensations are bound together by psychological laws, they constitute mind. When, as neutral elements, they are governed by physical laws, sensations constitute matter. ${ }^{\circ}$ Sensations are now the fundamental elements upon which both mind and matter are built as logical constructions (MPD, p. 139).

A further casualty of Russell's adoption of behaviourism and neutral monism is the ego as a momentary subject of consciousness. A scientific analysis of statements about the contents of the mind does not require any reference to the self or subject. To take an example, the statement "I am thinking" is more correctly expressed as "It is thinking in me", since this, in turn, can be expressed in terms of sensations and their psychological laws. We are misled by grammar, says Russell, into believing that there is a subject doing the experiencing. This is a fiction, as is the belief in an agent supposedly required for an action, expressed in a statement like "I am walking". ${ }^{4 I}$ Both the subject and the agent can be eliminated by regarding all mental phenomena as sensations, governed by causal laws linking them together, and requiring no reference to either consciousness or the subject of consciousness.

The extent to which Russell's behaviourist/neutral-monist philo-

${ }^{39} \mathrm{AMi}$, pp. 32, 36, 38, 297, 306-7.

$4^{\circ} A M i, \mathrm{pp} .30 \mathrm{O}-5$. For an analysis of these and other aspects of neutral monism, see Robert Tully, "Russell's Neutral Monism" in Antinomies and Paradoxes, Russell, 8 (1988): 209-24

${ }^{41} A M i$, pp. 17-18, 285-6. sophical psychology eliminates the need for any reference to an internal emotional life is brought home when he analyzes the concepts of repression and unconscious desire. These are particularly instructive examples because of his own repressive treatment of his son John. In the end, Russell regards both unconscious desires and repression as having relatively minor importance. What is important is that individuals learn to adopt habits necessary for life in the community in which they find themselves.

Russell believes that unconscious desire "is the natural primitive form of desire" from which conscious desire develops. Russell here opposes Freud's theory that all desires are originally conscious but are soon repressed into the realm of the unconscious:

On the contrary, we shall suppose that, although Freudian "repression" undoubtedly occurs and is important, it is not the usual reason for the unconsciousness of our wishes. The usual reason is merely that wishes are all, to begin with, unconscious, and only become known when they are actively noticed. (AMi, p. 39)

Individuals learn about their own desires, according to Russell, in precisely the same way in which they learn about the desires of others, namely through observing behaviour and inferring from this evidence the desire which prompted it. When they do so correctly, they become conscious of their own desires. The major reasons for individuals failing to do so are faulty education, laziness, and lack of experience (pp. 3I, 39, 72). In the case of his son John, Russell wished to avoid all of these contingencies and to ensure that the boy should come to observe the cause of his own behaviour as an irrational fear, purged by the "drastic measures" used to introduce him to the sea.

Russell goes on to reduce the notion of repression to a matter of conflicting habits. Like J. B. Watson, whom he quotes in support of this view, he does not accept the existence of the unconscious as a distinct mental realm:

Many of us do not believe in a world of the unconscious (a few of us even have grave doubts about the usefulness of the term consciousness), hence we try to explain censorship along ordinary biological lines. We believe that one group of habits can "down" another group of habits- those which we call expressive of our "real selves"-inhibit or quench (keep inactive or partially 

inactive) those habits and instinctive tendencies which belong largely in the
past. ${ }^{42}$

Thus, when individuals "censor" a habit or instinctive tendency, it is a matter of maintaining those habits expressive of their present selves over past habits or conflicting instincts. Similarly, when individuals inhibit an instinctive tendency unacceptable to civilized adult society, the instinct does not constitute a wish once conscious and then repressed into the unconscious. It is simply a tendency to behave in a certain manner at odds with the habits of the community at large. 43 Since affective conflict in the Freudian sense occurs only rarely, it is of minor importance. As a result, when confronted with the practical problem of dealing with a strongly rooted instinctive fear in children, Russell concerns himself with its control through the establishment of habit rather than with understanding the inner trauma which constitutes its root cause. Since John's instinctive fear of the sea was simply a tendency to behave in childish ways at odds with the habits of the adult community, it could best be dealt with by holding him under the waves and conditioning him against his will to the feel of the water.

Russell's behaviourist account of repression and unconscious desire shows quite clearly why he comes to regard the internal life of the emotions as unimportant in his philosophy of education. Having adopted the behaviourist/neutral-monist theory in his philosophical psychology, Russell then applies its theories to the raising of his own children, which he analyzes in On Education. The "drastic methods" that he adopts in treating John's instinctual fears are graphically described in that work, while his reasons for adopting such methods make sense in light of the behaviourist theory of unconscious desire and repression that he adopts in The Analysis of Mind. John could only rid himself of his fear of the sea, according to Russell, if he came to observe his behaviour as caused by an irrational aversion to the water. The best means for him to make this observation was by being forced to take the plunge into the brine. His yelling and screaming at

${ }^{42}$ J. B. Watson, "The Psychology of Wish Fulfillment", The Scientific Monthly, Nov. 1916, p. 483 , quoted in $A M i$, p. 39 .

43 Watson, p. 485 , quoted in $A M i$, p. 40. this point were simply evidence of one set of habits being "downed" by another set. They certainly did not indicate any deep trauma, simply an adjustment to a new set of habits to which he would soon become accustomed through a sense of pride and social approval. The cost to John's emotional life was clearly not a factor in Russell's concern to instill the correct set of habits in him. Yet, Katharine Tait tells us that John's fears did not go away in this or in other instances: "Behaviourist method triumphed and good sleeping habits were assured. But the fears remained. They grew and grew and grew, secretly, in John as in me, festering quietly and sapping our vitality." 44 All of this suggests that Russell's behaviourism was inadequate, at least in the case of his own children, for enabling them to overcome deeply held fears. This is because the theory takes no account of the internal reality of emotions or of the emotional traumas that repression could exact upon children's development.

\section{CONCLUSION}

In conclusion, I wish to emphasize four points:

(I) The fundamental differences between Russell's behaviourist concept of children and his earlier humanistic concept underline just how far he has moved away from process philosophy of education. It is Russell's rejection of the principle of growth as the unifying source of impulse, instinct, and desire that makes this move possible. The principle of growth had provided an "instinctive urgency" in children, guiding their development in ways analogous to such organisms as trees which naturally "seek the light". For the earlier Russell, children's organic nature guides them naturally towards learning. However, this belief was brushed aside by the mechanical behaviourism that he came to adopt according to which children learn best by being inculcated with the correct set of habits. No longer founded on any organic principle, the impulses, instincts, and desires of children are now to be moulded by means of habit formation along lines chosen by adults rather than based on children's own instinctual growth. This is pre-

44 My Father, p. 66. In a interview John Russell said that the method "worked in the end" but was "a bit cruel" (Norman Moss, CBC "Ideas", broadcast March 1977, Rec. Acq. 449 [tape]). 
cisely how Whitehead characterizes the construction of a mechanism, namely by using a vitality that comes from without rather than from within. Education, for Whitehead, however, should not proceed in this manner, since it is a matter of stimulating the process of growth and respecting the child's rhythmic cycles.

(2) It is Russell's deeply held conception of the scientific method as a process of analysis, separating out the distinct elements of a problem in order to make rational conclusions, that first attracts him to behaviourism and neutral monism. These two theories, which he merges in his own philosophical psychology, embody for Russell the positive tendencies of the scientific method. It is this method, therefore, that leads him away from process philosophy of education. Nor should this surprise us, since Russell's analytic conception of the scientific method distinguishes his philosophy from the process philosophy of Whitehead. I pointed to this important difference in the second section of the paper. Moreover, when Russell abandons his humanistic concept of children and adopts behaviourism, it is primarily because of the methodological advantages for studying both children and adults that he does so. In other words, the main attraction of both behaviourism and neutral monism for Russell is that they embody the scientific method. And it is this method of analysis that leads Russell away from process philosophy of education with its emphasis on organic growth, interdependence, and interrelatedness.

(3) Russell's attraction to neutral monism is a result of both the theory's scientific characteristics and the opportunity that it offers to throw a new light" on the problem of knowledge. The epistemological implications of Russell's adoption of neutral monism are that our knowledge of the external world is far less direct and "more abstract and mathematical" than in his earlier dualist theories, where sense-data comprise the major link between experience and reality. Because physical objects are now logical constructs from sensations and because our perception of them is complicated by both the physical and physiological processes involved, all that we can know of them are "abstract properties of structure" ( $H W P_{3}$, pp. 787, 788). Other than these, physical objects are a mystery to scientists and, by implication, to educators. and children. The familiarity that they may seem to have in our everyday experiences of colours, shapes, and sounds are misleading because these experiences fail to take into account the complexity that physics reveals as inherent in both the external world and our knowledge of it. In contrast, Whitehead believes that while the world revealed to us by physics may be very different from that of sense-experience, nevertheless, children's experiences of the world, however partial and prescientific, should be taken into account by educators in order that the process of growth be based upon their rhythmic cycle of romance. Failure to do so will mean that the later cycles of precision and generalization (in which they may learn the truths of physics) will be incomplete because they are lacking in romantic foundation..$^{45}$

(4) Russell's abandonment of a humanistic approach to education for a mechanistic one entails the diminution of children's freedom in both his philosophy and practice of education. The kind of classical conditioning that he uses in the upbringing of his own children, and recommends in the education of children in general, undermines the very freedom stemming from their impulses and organic growth that he advocated earlier. Convinced of the scientific rectitude of using behaviourist methods in education, Russell denies to his children the reality and worth of their emotions and the kind of self-expression that is based on these emotions. For Russell, children are to be moulded according to the dictates of the community in which they find themselves, particularly those communities that understand the importance of science ( $A M i$, pp. 39-40). Any notion of freedom based on the child's own cycles of growth and development he jettisons for the sake of scientific precision. ${ }^{46}$
45 Brumbaugh, Whitehead, Process Philosophy, and Education, pp. I5, I7.

${ }^{46}$ Nevertheless, for a coherent defence of Russell's account of the importance of emotions to education, see Mattai, "Education and the Emotions" (cited at n. 28). 